\title{
Patrizia Oppici, Un filo di pietà. Aspetti della compassione nella narrativa francese da Flaubert a Proust
}

\section{Emanuele Kanceff}

\section{(2) OpenEdition \\ 1 Journals}

\section{Edizione digitale}

URL: https://journals.openedition.org/studifrancesi/39773

DOI: $10.4000 /$ studifrancesi.39773

ISSN: 2421-5856

\section{Editore}

Rosenberg \& Sellier

\section{Edizione cartacea}

Data di pubblicazione: 1 décembre 2004

Paginazione: 409

ISSN: 0039-2944

\section{Notizia bibliografica digitale}

Emanuele Kanceff, «Patrizia Oppici, Un filo di pietà. Aspetti della compassione nella narrativa francese da Flaubert a Proust», Studi Francesi [Online], 143 (XLVIII | II) | 2004, online dal 30 novembre 2015, consultato il 19 mai 2021. URL: http://journals.openedition.org/studifrancesi/39773 ; DOI: https:// doi.org/10.4000/studifrancesi.39773

Questo documento è stato generato automaticamente il 19 mai 2021.

\section{cc) $(9)$}

Studi Francesi è distribuita con Licenza Creative Commons Attribuzione - Non commerciale - Non opere derivate 4.0 Internazionale. 


\title{
Patrizia Oppici, Un filo di pietà. Aspetti della compassione nella narrativa francese da Flaubert a Proust
}

\author{
Emanuele Kanceff
}

\section{NOTIZIA}

PATRIZIA OPPICI, Un filo di pietà. Aspetti della compassione nella narrativa francese da Flaubert a Proust, Bologna, CLUEB, 2001 («Strumenti», 19), pp. 191.

1 Patrizia Oppici ha raccolto in questo volume sei saggi che sono strettamente legati l'uno all'altro e che quindi convivono perfettamente in volume. Due di essi, quello su Paul Bourget e quello su Anatole France, sono inediti, ma i limiti temporali non ci consentono di occuparcene, così come del primo, quello su Flaubert. Rimangono per noi quelli su Schwob, Ghéon e Proust, nessuno dei quali inedito.

2 Tuttavia, in una bella introduzione, l'A. ci dà molto bene le chiavi di collegamento e di lettura del complesso di questi scritti, nati dalla volontà di indagare l'origine tardoottocentesca del sentimento della pietà nella letteratura francese, di derivazione tedesca e russa, e che bene sopperisce al bisogno di opporsi alla freddezza del realismo naturalista. Nel suo complesso, il libro offre una bella e interessante panoramica di questa nuova sensibilità e dei suoi sviluppi. 